\title{
Kandungan Pb Pada Daun Angsana (Pterocarpus indicus) dan Rumput Gajah Mini (Axonopus.Sp)Di Jalan Protokol Kota Tangerang
}

\author{
${ }^{1}$ Siti Nihayatul Inayah, ${ }^{1,2}$ Thamzil Las, ${ }^{1,2}$ Etyn Yunita \\ ${ }^{1)}$ Program Studi Kimia FST UIN Syarif Hidayatullah Jakarta \\ ${ }^{2)}$ Pusat Laboratorium Terpadu UIN Syarif Hidayatullah Jakarta
}

\begin{abstract}
Abstrak
Telah dilakukan penelitian untuk mengetahui akumulasi $\mathrm{Pb}$ pada daun Angsana (Pterocarpus indicus) dan rumput Gajah Mini (Axonopus.Sp) yang terletak dibeberapa jalan protokol Kota Tangerang. Lokasi pengambilan sampel dilakukan di Sembilan lokasi utama Kota Tangerang dan satu di lokasi permukiman. Pengambilan sampel dilakukan pada bulan Maret dan April 2009. Sampel dianalisa menggunakan Spektroskopi Serapan Atom (SSA) melalui metode destruksi basah. Hasil yang didapat dari penelitian ini adalah kandungan $\mathrm{Pb}$ pada daun Angsana (2.04 $7.30 \mu \mathrm{g} / \mathrm{g}$ pada bulan Maret $2009 ; 1.12-7.61 \mu \mathrm{g} / \mathrm{g}$ pada bulan April 2009) dan rumput Gajah Mini $(2.12$ - $12.38 \mu \mathrm{g} / \mathrm{g}$ pada bulan Maret $2009 ; 5.89-10.32 \mu \mathrm{g} / \mathrm{g}$ pada bulan April 2009). Secara umum dapat disimpulkan bahwa Pterocarpus indicus dan Axonopus.Sp mampu mengakumulasi $\mathrm{Pb}$ pada kisaran 1.12-12.38 $\mu \mathrm{g} / \mathrm{g}$. Kandungan $\mathrm{Pb}$ pada daun Angsana dan rumput Gajah Mini hasil penelitian tidak mencapai 1000 ppm $(\mu \mathrm{g} / \mathrm{g})$. Hal ini berarti kandungan $\mathrm{Pb}$ pada daun Angsana dan rumput Gajah Mini di Kota Tangerang belum melampaui ambang batas toksisitasnya terhadap tanaman.
\end{abstract}

Kata kunci : Daun Angsana, Rumput Gajah Mini, Tanaman, Timbal (Pb)

\begin{abstract}
A research has been conducted to determine the accumulation of $\mathrm{Pb}$ in the Angsana leaves (Pterocarpus indicus) and Gajah Mini grasses (Axonopus. Sp) located on major streets in Tangerang City. The sampling locations are in nine main locations in Tangerang City and a residential location. The sampels takes on March and April 2009, and analyzed of $\mathrm{Pb}$ using Atomic Absorption Spectroscopy (AAS) within wet destruction method. The results of this study was the $\mathrm{Pb}$ contents in the Angsana leaves (2.04 to $7.30 \mu \mathrm{g} / \mathrm{g}$ in March 2009; $1.12-7.61 \mu \mathrm{g} / \mathrm{g}$ in April 2009) and Gajah Mini grasses (2.12 to $12.38 \mu \mathrm{g} / \mathrm{g}$ in March $2009 ; 5.89-10.32 \mu \mathrm{g} / \mathrm{g}$ in April 2009). It's generally can be concluded that Axonopus.Sp and Pterocarpus indicus are able to acumulate $\mathrm{Pb}$ in range 1.12-12.38 $\mu \mathrm{g} / \mathrm{g}$. Contents of $\mathrm{Pb}$ on Angsana leaves and Gajah Mini grasses of the research has been done do not reach $1000 \mathrm{ppm}(\mu \mathrm{g} / \mathrm{g})$. Its means that the contents of $\mathrm{Pb}$ on Angsana leaves and Gajah Mini grasses in Tangerang City are not exceed toxicity threshold for plants.
\end{abstract}

Keywords: Angsana Leaves, Gajah Mini Grasses, Plants, Lead(Pb)

\section{PENDAHULUAN}

Udara merupakan faktor penting dalam kehidupan. Perubahan lingkungan udara pada umumnya disebabkan pencemaran udara, yaitu masuknya zat pencemar (berbentuk gas-gas dan partikel kecil/aerosol) ke dalam udara. Selain dari alam, pencemaran udara juga diakibatkan oleh aktivitas manusia terutama dari asap kendaraan dan gas buangan dari industri. Bahan pencemar udara diantaranya adalah partikel debu dan $\mathrm{Pb}$ (Soedomo, 1999).
Adanya $\mathrm{Pb}$ didalam tubuh manusia dapat menghambat aktivitas enzim yang terlibat dalam pembentukan hemoglobin $(\mathrm{Hb})$. Penghambatan pembentukan hemoglobin $(\mathrm{Hb})$ mengakibatkan terjadinya anemia. Logam $\mathrm{Pb}$ bisa merusak jaringan saraf, fungsi ginjal, menurunnya kemampuan belajar, dan membuat anak-anak bersifat hiperaktif. Selain itu $\mathrm{Pb}$ juga mempengaruhi organ-organ tubuh antara lain sistem saraf, ginjal, sistem reproduksi, sistem endokrin dan jantung, serta gangguan pada otak sehingga anak mengalami 
gangguan kecerdasan dan mental (Widowati et.al., 2008).

Melihat besarnya dampak negatif $\mathrm{Pb}$ terhadap manusia maka diperlukan tindakan untuk mereduksi $\mathrm{Pb}$ dari udara. Salah satu metode untuk menanggulangi pencemaran $\mathrm{Pb}$ di udara adalah dengan menggunakan tanaman yang dikenal dengan istilah fitoremediasi. Pohon Angsana (Pterocarpus indicus) merupakan salah satu vegetasi yang mampu mengurangi pencemaran udara dan mengakumulasi logam berat seperti $\mathrm{Pb}$ (Widowati et.al., 2008).

Pohon Angsana juga merupakan pohon peneduh jalan yang banyak dijumpai di jalanjalan utama Kota Tangerang, selain rumput Gajah Mini sebagai tanaman hias penutup jalan. Kedua tanaman ini memiliki morfologi daun yang berbeda. Menurut Sastrawijaya (1996), ukuran dan jumlah stomata sangat mempengaruhi partikulat $\mathrm{Pb}$ di udara masuk ke dalam jaringan daun.

Bioakumulasi $\mathrm{Pb}$ terhadap daun pada tanaman akan lebih banyak terjadi pada tanaman di pinggir jalan besar yang padat kendaraan bermotor (Antari dan Sundra, 2002). Untuk mengetahui seberapa besar akumulasi $\mathrm{Pb}$ pada daun Angsana dan rumput Gajah Mini dijalan utama Kota Tangerang maka diperlukan studi tentang hal tersebut.

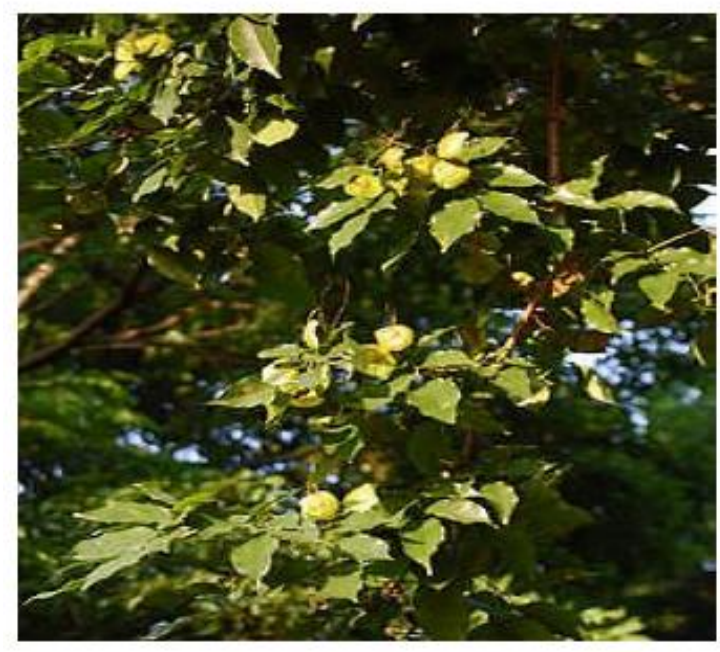

Gambar 1. Ranting daun Angsana

Penelitiaan ini dilakukan untuk memberikan informasi tentang kemampuan daun Angsana (Pterocarpus indicus) dan rumput Gajah Mini (Axonopus.sp) dalam mengakumulasi $(\mathrm{Pb})$ yang dihasilkan oleh asap kendaraan bermotor yang melintasi jalan-jalan protokol di Kota Tangerang. Dengan penelitian ini juga diharapkan dapat diketahui tingkat pencemaran udara ambien berdasarkan parameter $\mathrm{Pb}$ sebagai salah satu variabel pencemar.

\section{METODE PENELITIAN}

\section{Waktu \& Tempat Penelitian}

Penelitian dilakukan pada bulan Maret hingga Mei 2009 di Jalan-jalan Utama Kota Tangerang. Pengambilan sampel dilakukan di sembilan titik yaitu Jalan Veteran, Jl. Daan Mogot 3, Jl. M.Yamin, Jl. DR. Sitanala, Jl. Kali Pasir, Jl. Perintis Kemerdekaan I, Jl. Perintis Kemerdekaan II, Jl. A.Yani, TMP. Taruna dan Jl. Irian Jaya (lokasi daerah permukiman). Analisa $\mathrm{Pb}$ dilakukan di Laboratorium Analisa Lingkungan, Pusat Laboratorium Terpadu UIN Syarif Hidayatullah Jakarta.

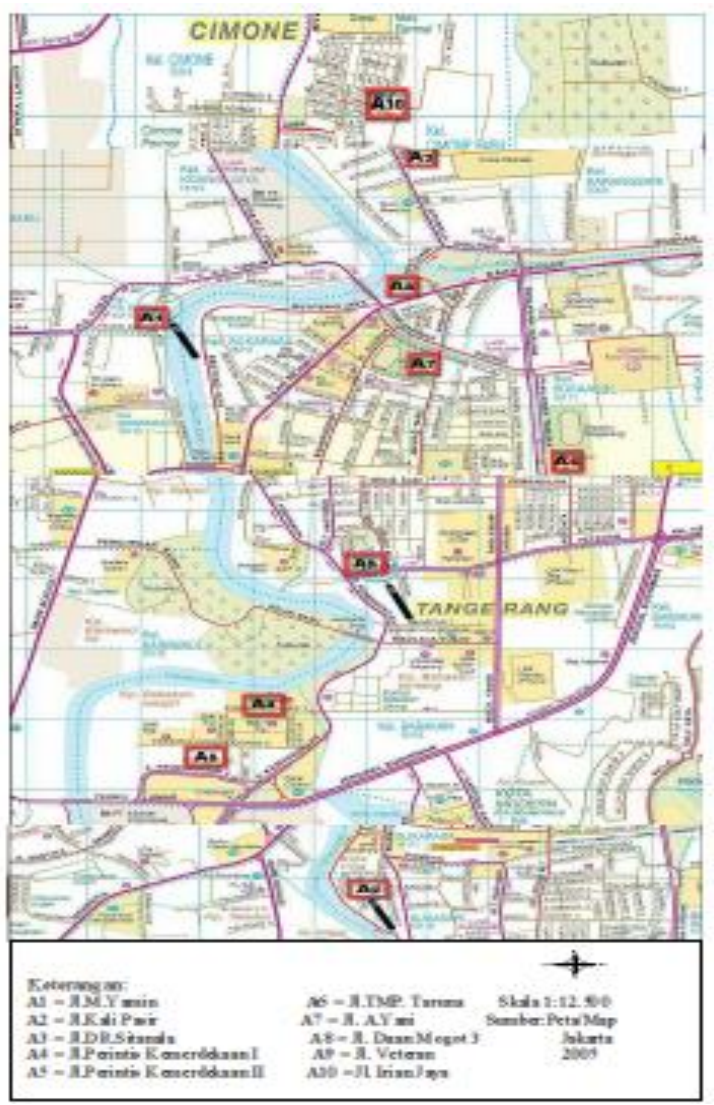

Gambar 2. Lokasi Sampling

Bahan dan Alat 
Alat yang digunakan dalam penelitian ini yaitu: hand tally counter, stopwatch, pisau, gunting, kantong plastik, meteran, pinset, timbangan analitik (OHAUS), oven, mortal, hot plate, Atomic Absorption Spectrophotometer (AAS) (Merk Perkin Elmer, Tipe AA-700) dan tisu.

Bahan yang digunakan terdiri dari asam nitrat $(\mathrm{HNO} 3)$, asam perklorat $(\mathrm{HClO} 4) 70 \%$, dan aquadest dan larutan standar $\mathrm{Pb} 1000$ $\mathrm{mg} / \mathrm{L}$.

\section{Pengambilan Sampel}

Sampel yang digunakan dalam penelitian yaitu : daun Angsana (Pterocarpus indicus) dan rumput Gajah Mini (Axsonopus.sp) yang tumbuh di sepanjang jalan protokol kota Tangerang. Teknik pengambilan sampel bersifat purposive sampling. Sampel diambil pada 9 jalan utama di Kota Tangerang dan 1 lokasi daerah permukiman. Untuk mengetahui kepadatan lalu lintas, pada setiap titik dari sepuluh lokasi jalan dilakukan penghitungan jumlah kendaraan bersamaan dengan waktu sampling yaitu selama satu jam. Satu sampel daun Angsana (Pterocarpus indicus) dan satu sampel rumput Gajah Mini (Axsonopus.sp) diambil pada masing-masing lokasi (Jalan Veteran, Jl. Daan Mogot 3, Jl. DR.Sitanala, Jl. M.Yamin, Jl. Kali Pasir, Jl. Printis Kemerdekaan I, Jl. Perintis Kemerdekaan II, Jl. Jend.A.Yani, Jl. TMP.Taruna, dan Jl. Irian Jaya).

Daun Angsana yang digunakan sebagai sampel adalah daun bewarna hijau tua di bagian ranting yang paling bawah dekat dengan jalan. Selanjutnya daun Angsana di potong dari ranting pohon menggunakan gunting dengan hati-hati. Sampel tersebut diambil menggunakan pinset dan dimasukkan kedalam kantong plastik. Pengambilan sampel rumput Gajah Mini (Axsonopus.sp) dilakukan dengan cara rumput Gajah Mini dipotong pada pangkalnya, tidak sampai akar. Sampel tersebut di ambil menggunakan pinset lalu di masukkan kedalam kantong plastik. Selanjutnya masing-masing sampel (daun Angsana dan rumput Gajah Mini) dibawa ke Laboratorium Analisa Lingkungan Pusat Laboratorium Terpadu UIN Syarif Hidayatullah Jakarta untuk ditentukan kadar Pb-nya.

\section{Preparasi Sampel}

Preparasi sampel dilakukan dengan metode destruksi basah (wet method). Sampel (daun Angsana dan rumput Gajah Mini) diambil 2 gr lalu ditaruh pada cawan porselen. Sampel kemudian dikeringkan dalam oven bersuhu $105^{\circ} \mathrm{C}$ sampai beratnya konstan. Selanjutnya sampel dipotong kecil-kecil dan ditempatkan dalam gelas piala, lalu ditambahkan $10 \mathrm{ml} \mathrm{HNO}_{3} 65 \%$, didiamkan semalaman. Setelah itu sampel didestruksi dengan menggunakan labu destruksi sampai menghasilkan gas $\mathrm{NO}_{2}$ yang berwarna kemerahan. Selanjutnya gelas piala tersebut didinginkan dan ditambahkan 2 - $4 \mathrm{ml} \mathrm{HClO}_{4}$ 70\%. Sampel dipanaskan kembali dan dibiarkan menguap hingga volumenya rendah. Setelah itu sampel dipindahkan ke labu ukur $50 \mathrm{ml}$ lalu diencerkan dengan air suling sampai tanda tera. Sampel selanjutnya siap untuk dianalisis menggunakan AAS.

\section{Pembuatan Larutan Standar}

Larutan baku $\mathrm{Pb} 100 \mathrm{mg} / \mathrm{L}$ dibuat dari larutan induk $\mathrm{Pb} 1.000 \mathrm{mg} / \mathrm{L}$, di pipet $10 \mathrm{~mL}$ dan dimasukkan ke dalam labu ukur $100 \mathrm{~mL}$; diencerkan dengan air suling sampai tepat pada tanda tera, lalu dihomogenkan. Untuk larutan kerja $\mathrm{Pb} 10 \mathrm{mg} / \mathrm{L}$ dibuat dari larutan baku $\mathrm{Pb}$ $100 \mathrm{mg} / \mathrm{L}$.

\section{Pembuatan Kurva Kalibrasi (Pb)}

Larutan standar $\mathrm{Pb}$ dibuat dengan mengencerkan larutan $\mathrm{Pb} 10 \mathrm{mg} / \mathrm{L}$ hingga diperoleh konsentrasi yang diinginkan dengan range $0-3 \mathrm{mg} / \mathrm{L}$. Selanjutnya masing-masing larutan standar diukur absorbansinya dengan menggunakan AAS AA-700 Perkin Elmer menggunakan lampu hollow cathode $\mathrm{Pb}$.

\section{Pengukuran Sampel}

Pengukuran sampel dilakukan menurut Metode Pengujian Kadar $\mathrm{Pb}$ sesuai dengan SNI nomor 06-698945 tahun 2005.

\section{Perhitungan Kadar Pb Daun :}

$$
\mathrm{C}^{\prime}{ }^{\prime}=\left(\mathrm{C} y \times \frac{V}{w}\right) \times 1000
$$

Keterangan:

Cy' = kandungan $\mathrm{Pb}$ pada daun $(\mu \mathrm{g} / \mathrm{g})$

$\mathrm{Cy}=$ konsentrasi $\mathrm{Pb}$ terukur pada AAS 


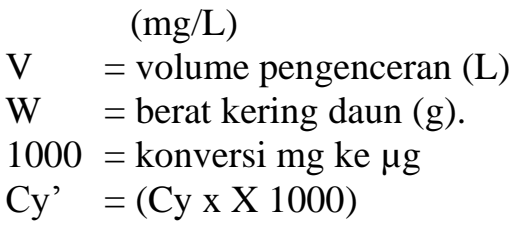

\section{HASIL DAN PEMBAHASAN}

\section{Kandungan Pb Daun Angsana dan Rumput Gajah Mini}

Kandungan $\mathrm{Pb}$ daun Angsana di jalanjalan utama Kota Tangerang dapat dilihat pada Tabel 1 berikut :

Tabel 1. Kandungan $\mathrm{Pb}$ Daun Angsana dan Rumput Gajah Mini di Lokasi Penelitian pada Bulan Maret dan April 2009.

\begin{tabular}{|c|c|c|c|c|c|}
\hline \multirow[b]{2}{*}{ No. } & \multirow[b]{2}{*}{ Lokasi Pengambilan Sampel } & \multicolumn{2}{|c|}{ Bulan Marat 2009} & \multicolumn{2}{|c|}{ Bulan April 2009} \\
\hline & & $\begin{array}{c}\text { Daun } \\
\text { Angsana } \\
\text { (Hgg) }\end{array}$ & $\begin{array}{c}\text { Runput } \\
\text { (Gajah Nifini } \\
\text { (Hgg g }\end{array}$ & $\begin{array}{l}\text { Daun } \\
\text { Angsana } \\
\text { ( } \mu g g \text { g) }\end{array}$ & $\begin{array}{c}\text { Rumput } \\
\text { Gajaj Mimi } \\
\text { ( } \mu g g \text { ) }\end{array}$ \\
\hline 1. & JMLYamin & 2.04 & 2.12 & 7.50 & 6.05 \\
\hline 2 & JKali Pasir & 4.28 & 2.65 & 7.61 & 5.89 \\
\hline 3. & JDRR.Sitanala & 4.57 & 8.33 & 5.06 & 6.38 \\
\hline 4 & JlPerintis Kemzrddkaan I & 3.84 & 4.63 & 5.42 & 799 \\
\hline 5 & JlPerintis Kemerddkaan II & 7,30 & 6.84 & 4.00 & 10.14 \\
\hline 6. & JTMP.Taruna & 4.45 & 5.63 & 4.07 & 9.86 \\
\hline 7. & Jl.Ahmad Yani & 5.36 & 12.38 & 2.51 & 7.59 \\
\hline 8. & JLDaan Mogot 3 & 2.64 & 5.93 & 1.12 & 9.60 \\
\hline 9. & JVeteran & 4.92 & 7,36 & 6.85 & 9,72 \\
\hline 10 . & Jllian Jaya & 4.90 & 1024 & 6.47 & 10.32 \\
\hline
\end{tabular}

Berdasarkan Tabel 1 kandungan $\mathrm{Pb}$ pada masing-masing lokasi sampling bervariasi, baik pada daun Angsana maupun rumput Gajah Mini. Akumulasi $\mathrm{Pb}$ daun Angsana pada bulan Maret 2009 berkisar antara $2.04-7.30$ $\mu \mathrm{g} / \mathrm{g}$, dan bulan April 1.12 - $7.61 \mu \mathrm{g} / \mathrm{g}$. Adapun akumulasi $\mathrm{Pb}$ dalam rumput Gajah Mini berkisar antara $2.12-12.38 \mu \mathrm{g} / \mathrm{g}$ pada bulan Maret dan $5.89-10.32 \mu \mathrm{g} / \mathrm{g}$ pada bulan April 2009.

Menurut Siregar (2005), secara normal kandungan $\mathrm{Pb}$ dalam berbagai jenis tanaman berkisar antara 0,5 - 3,0 $\mu \mathrm{g} / \mathrm{g}$, atau dengan kata lain kandungan maksimal $\mathrm{Pb}$ dalam tanaman adalah 3,0 $\mu \mathrm{g} / \mathrm{g}$. Berdasarkan batasan ini maka dapat diketahui bahwa kandungan $\mathrm{Pb}$ dalam daun Angsana yang ada di beberapa jalan utama Kota Tangerang sekitar $85 \%$ sudah melebihi batas normal kandungan $\mathrm{Pb}$ pada tanaman. Sedangkan kandungan $\mathrm{Pb}$ rumput Gajah Mini, mayoritas juga ( $90 \%$ ) sudah melebihi batas normal kandungan $\mathrm{Pb}$ pada tanaman.

Secara keseluruhan kandungan $\mathrm{Pb}$ pada daun Angsana dan rumput Gajah Mini dari hasil penelitian ini tidak mencapai 1000 ppm $(\mu \mathrm{g} / \mathrm{g})$. Partikel $\mathrm{Pb}$ yang diserap oleh tanaman akan memberikan efek buruk apabila kepekatannya berlebihan. Pengaruh yang ditimbulkan antara lain dengan adanya penurunan pertumbuhan dan produktivitas tanaman serta kematian. Menurut Sunarya dkk, (1991), batas toksisitas logam berat $\mathrm{Pb}$ pada tanaman tingkat tinggi adalah 1000 ppm $(\mu \mathrm{g} / \mathrm{g})$. Dari hasil penelitian ini kandungan $\mathrm{Pb}$ pada daun Angsana dan rumput Gajah Mini di Kota Tangerang masing belum melampaui batas toksisitasnya terhadap tanaman.

\section{Pengaruh Morfologi Daun terhadap Kandungan Pb Daun Angsana dan Rumput Gajah Mini}

Adanya perbedaan kandungan $\mathrm{Pb}$ pada daun Angsana dan rumput Gajah Mini pada hasil penelitian ini diduga karena adanya perbedaan jenis tanaman dan morfologi daun tanaman tersebut. Menurut Antari dan Sundra (2002) serta Siregar (2005), terdapat perbedaan kandungan $\mathrm{Pb}$ pada jenis tanaman yang berbeda.

Morfologi daun Angsana berbentuk oval, permukaan daun lebar dan licin sedangkan rumput Gajah Mini berbentuk daun jarum, permukaan daun sempit serta kasar. Rachmawati (2005) menyatakan bahwa penyerapan $\mathrm{Pb}$ melalui daun terjadi karena partikel $\mathrm{Pb}$ di udara jatuh dan mengendap pada permukaan daun.

Jumlah dan ukuran stomata pada daun mempengaruhi banyaknya kandungan $\mathrm{Pb}$ yang terjerap. Semakin banyak dan besar stomata pada daun, maka makin banyak $\mathrm{Pb}$ yang terjerap. Daun jarum mempunyai stomata lebih banyak daripada daun lebar, sehingga tanaman berdaun jarum lebih efektif dalam menjerap $\mathrm{Pb}$ di udara dibandingkan tanaman berdaun lebar.

Penjelasan yang sama dikemukakan oleh Wedling dalam Antari dan Sundra (2002), yang menyatakan penyerapan $\mathrm{Pb}$ pada daun terjadi karena partikel $\mathrm{Pb}$ di udara masuk ke dalam daun melalui proses penyerapan pasif. Masuknya partikel $\mathrm{Pb}$ ke dalam jaringan daun sangat dipengaruhi oleh ukuran dan jumlah dari stomata. Semakin besar ukuran dan 
semakin banyak jumlah stomatanya maka semakin besar pula penyerapan $\mathrm{Pb}$ masuk ke dalam daun.

Hasil penelitian Sembiring \& Sulistyawati (2006) menunjukkan $\mathrm{Pb}$ rata-rata pada daun S. Marcrophylla lebih kecil dari hasil penelitian ini yaitu sebesar $0.22-0.65$ ppm $(\mu \mathrm{g} / \mathrm{g})$. Sedangkan penelitian Antari \& Sundra (2002) menemukan kandungan $\mathrm{Pb}$ pada daun Angsana dan daun Glondongan yang lebih besar dari hasil penelitian ini yaitu 115 $220 \mathrm{ppm}(\mu \mathrm{g} / \mathrm{g})$. Adapun kandungan $\mathrm{Pb}$ ratarata pada rumput dari hasil penelitian Surtipanti dkk (1983) menunjukkan konsentrasi yang lebih besar dari hasil penelitian ini yaitu $6.5-55.9 \mathrm{ppm}(\mu \mathrm{g} / \mathrm{g})$.

Selain jenis tanaman dan morfologi daun yang berbeda, adanya perbedaan lokasi, waktu, cuaca, dan metode penelitian yang digunakan diduga menyebabkan adanya perbedaan kandungan $\mathrm{Pb}$ pada beberapa tanaman dari berbagai penelitian ini.

\section{Pengaruh Jumlah Kendaraan terhadap Kandungan Pb Daun Angsana dan Rumput Gajah Mini}

Jumlah kendaraan yang melintasi sepuluh lokasi penelitian ditentukan dengan cara selama pengambilan sampel (sampling) dapat dilihat pada Tabel 2.

Tabel 2. Jumlah Kendaraan pada Lokasi Penelitian Selama Sampling.

\begin{tabular}{|c|l|c|c|}
\hline \multirow{2}{*}{ No } & $\begin{array}{l}\text { Lokasi pengambilan } \\
\text { sampel }\end{array}$ & $\begin{array}{c}\text { Bulan } \\
\text { Maret } \\
2009\end{array}$ & $\begin{array}{c}\text { Bulan } \\
\text { April } \\
2009\end{array}$ \\
\cline { 3 - 4 } & \multicolumn{1}{|l|}{$\begin{array}{c}\text { Jumlah } \\
\text { Total }\end{array}$} & $\begin{array}{c}\text { Jumlah } \\
\text { Total }\end{array}$ \\
\hline 1. & Jl.M.Yamin & 1296 & 3914 \\
\hline 2. & Jl.Kali Pasir & 3888 & 4208 \\
\hline 3. & Jl.Dr.Sitanala & 1735 & 2868 \\
\hline 4. & $\begin{array}{l}\text { Jl.Printis } \\
\text { Kemerdekaan I }\end{array}$ & 2220 & 2550 \\
\hline 5. & $\begin{array}{l}\text { Jl.Printis } \\
\text { Kemerdekaan II }\end{array}$ & 2932 & 3518 \\
\hline 6. & Jl.TMP.Taruna & 2617 & 3204 \\
\hline 7. & Jl.A.Yani & 1390 & 1652 \\
\hline 8. & Jl.Daan Mogot 3 & 3962 & 4620 \\
\hline 9. & Jl.Veteran & 2350 & 2430 \\
\hline 10. & Jl.Irian Jaya & 450 & 480 \\
\hline
\end{tabular}

Pada bulan Maret 2009, kandungan $\mathrm{Pb}$ tertinggi dalam daun Angsana terdapat di Jalan Perintis Kemerdekaan II $(7.30 \mu \mathrm{g} / \mathrm{g})$. Tingginya kandungan $\mathrm{Pb}$ daun Angsana ini diduga karena lokasi tersebut banyak dilalui kendaraan bermotor, yaitu \pm 2932 (Tabel 2) .
Hal ini sejalan dengan pernyataan Sulasmini dkk. (2005), bahwa sejumlah Pb di dalam dan permukaan daun dipengaruhi oleh banyaknya kendaraan bermotor. Kandungan $\mathrm{Pb}$ tertinggi pada rumput Gajah Mini yaitu $12.38 \mu \mathrm{g} / \mathrm{g}$ terdapat di Jalan Ahmad Yani. Tingginya kandungan $\mathrm{Pb}$ dalam rumput Gajah Mini diduga karena letaknya yang lebih dekat dengan sumber emisi. Sedangkan kandungan $\mathrm{Pb}$ terendah pada daun Angsana $(2.04 \mu \mathrm{g} / \mathrm{g})$ dan rumput Gajah Mini $(2.12 \mu \mathrm{g} / \mathrm{g})$ terdapat di Jalan M.Yamin.

Rendahnya kandungan $\mathrm{Pb}$ ini diduga karena di lokasi tersebut terdapat pohon peneduh lain selain pohon Angsana sehingga $\mathrm{Pb}$ dapat diserap oleh lebih banyak tanaman. Seperti dikemukakan Siregar (2005) bahwa banyaknya tanaman penutup serta jenis tanaman di sekeliling tanaman tersebut merupakan faktor yang mempengaruhi kandungan $\mathrm{Pb}$ pada tanaman.

Pada bulan April 2009, kandungan $\mathrm{Pb}$ tertinggi dalam daun Angsana terdapat di Jalan Kali Pasir $(7.61 \mu \mathrm{g} / \mathrm{g})$. Tingginya kandungan $\mathrm{Pb}$ tersebut didugakarena lokasi tersebut banyak dilalui kendaraan bermotor yaitu sekitar 4208 (Tabel 2). Menurut Antari dan Sundra (2002), semakin banyak jumlah kendaraan bermotor yang lewat pada suatu jalan raya maka semakin tinggi pula kandungan polutan $\mathrm{Pb}$ yang di emisikan ke lingkungan sekitar. Adapun kandungan $\mathrm{Pb}$ terendah dalam daun Angsana pada bulan April 2009 terdapat di Jalan Daan Mogot 3 yaitu sebesar $1.12 \mu \mathrm{g} / \mathrm{g}$. Rendahnya kandungan $\mathrm{Pb}$ ini diduga karena di lokasi tersebut terdapat pohon peneduh yang lain. Kandungan $\mathrm{Pb}$ tertinggi pada rumput Gajah Mini yaitu (10.14 $\mu \mathrm{g} / \mathrm{g}$ ) terdapat di Jalan Perintis Kemerdekaan II, dan kandungan $\mathrm{Pb}$ terendah pada rumput Gajah Mini yaitu $(5.89 \mu \mathrm{g} / \mathrm{g})$ terdapat di Jalan Kali Pasir.

Logam $\mathrm{Pb}$ merupakan logam berat yang memiliki sifat larut dalam larutan asam. Air hujan dipengaruhi oleh pencemar atmosfer dan air hujan biasanya bersifat asam. Penambahan keasaman biasanya disebabkan oleh tiga asam mineral yaitu sulfat, nitrat dan hidroklorat. Mengingat air hujan bersifat asam sehingga besar kemungkinan berkurangnya $\mathrm{Pb}$ pada daun Angsana dan rumput Gajah Mini disebabkan karena larutnya $\mathrm{Pb}$ oleh air hujan tersebut. Partikel $\mathrm{Pb}$ dari emisi kendaraan bermotor mempunyai diameter antara $0.004-$ 
$1.00 \mu \mathrm{m}$ dengan rata-rata $0.2 \mu \mathrm{m}$. Partikel yang besar akan jatuh sedangkan partikel yang lebih kecil akan melayang lebih lama dan akhirnya jatuh kepermukaan daun atau ke tanah. Dengan demikian, tingkat sebaran polutan beragam antar ketinggian dari permukaan tanah sedangkan jumlah dan sebaran daun tanaman beragam antara tajuk dan batang. Untuk mengatasi kondisi tersebut,

dapat dilakukan dengan kombinasi jenis tanaman, sehingga polutan yang melayang lebih tinggi dapat dijerap oleh pepohonan, sedangkan yang melayang pada ketinggian yang lebih rendah atau jatuh dijerap oleh tanaman penutup tanah (Widagdo, 2005).

\section{Perbedaan kandungan Pb Daun Angsana dan Rumput Gajah Mini pada Masing- masing Lokasi Penelitian}

Berdasarkan uji ANOVA pada selang kepercayaan 95\%, diketahui bahwaterdapat perbedaan nyata kandungan $\mathrm{Pb}$ daun Angsana disetiap masing-masing lokasi, begitu juga kandungan $\mathrm{Pb}$ rumput Gajah Mini. Artinya bahwa secara statistik kandungan $\mathrm{Pb}$ yang terserap pada daun Angsana dan rumput Gajah Mini di masing-masing lokasi penelitian memiliki perbedaan. Perbedaan ini diduga karena banyaknya faktor yang mempengaruhi kandungan $\mathrm{Pb}$ dalam tanaman seperti jangka waktu tanaman kontak dengan $\mathrm{Pb}$, kandungan $\mathrm{Pb}$ dalam tanah, morfologi dan fisiologi tanaman, umur tanaman, faktor yang mempengaruhi areal serta jenis tanaman di sekeliling tanaman tersebut (Sukarsono, 1998).

Sidik ragam pengaruh lokasi penelitian terhadap kandungan $\mathrm{Pb}$ daun Angsana maupun rumput Gajah Mini dapat dilihat pada Tabel 3 dan Tabel 4.

Tabel 3. Sidik Ragam Pengaruh Lokasi Penelitian terhadap Kandungan $\mathrm{Pb}$ Daun Angsana

\begin{tabular}{|c|c|c|c|c|c|}
\hline $\begin{array}{c}\text { Sumber } \\
\text { Keragaman }\end{array}$ & $\begin{array}{c}\text { Jumlah } \\
\text { Kuadrat }\end{array}$ & $\begin{array}{c}\text { Derajat } \\
\text { Bebas }\end{array}$ & $\begin{array}{c}\text { Kuadrat } \\
\text { Tengah }\end{array}$ & F-hitung & Sig. \\
\hline Perlakuan & 1.991 & 1 & 1.991 & 0.590 & 0.453 \\
\hline Galat & 60.777 & 18 & 3.377 & & \\
\hline Total & 62.768 & 19 & & & \\
\hline
\end{tabular}

Tabel 4. Sidik Ragam Pengaruh Lokasi Penelitian terhadap Kandungan Pb Rumput Gajah Mini

\begin{tabular}{|c|c|c|c|c|c|}
\hline $\begin{array}{c}\text { Sumber } \\
\text { Keragaman }\end{array}$ & $\begin{array}{c}\text { Jumlah } \\
\text { Kuadrat }\end{array}$ & $\begin{array}{c}\text { Derajat } \\
\text { Bebas }\end{array}$ & $\begin{array}{c}\text { Kuadrat } \\
\text { Tengah }\end{array}$ & F-hitung & Sig. \\
\hline Perlakuan & 15.190 & 1 & 15.190 & 2.279 & 0.453 \\
\hline Galat & 119.963 & 18 & 6.665 & & \\
\hline Total & 135.153 & 19 & & & \\
\hline
\end{tabular}

\section{KESIMPULAN DAN SARAN}

\section{Kesimpulan}

1. Akumulasi $\mathrm{Pb}$ dalam Daun Angsana (Pterocarpus indicus) sebesar 2.04-7.30 $\mu \mathrm{g} / \mathrm{g}$ pada bulan Maret 2009 ; dan $1.12-$ $7.61 \mu \mathrm{g} / \mathrm{g}$ pada bulan April 2009, sedangkan akumulasi $\mathrm{Pb}$ pada rumput Gajah Mini sebesar $2.12-12.38 \mu \mathrm{g} / \mathrm{g}$ pada bulan Maret dan $5.89-10.32 \mu \mathrm{g} / \mathrm{g}$ pada bulan April 2009.

2. Kandungan $\mathrm{Pb}$ pada daun Angsana dan rumput Gajah Mini hasil penelitian di beberapa jaran protokol Kota Tangerang belum melampaui ambang batas toksisitas terhadap tanaman.

\section{Saran}

Perlu dilakukan penelitian lebih lanjut tentang pencemaran udara di Kota Tanggerang terhadap tanaman jenis lain, sehingga pemerintahan Pusat Kota Tanggerang dapat mengatasi pencemaran udara dengan cara yang lebih efisien.

\section{UCAPAN TERIMA KASIH}

Pada kesempatan ini penulis mengucapkan terimakasih kepada Kepala Pusat laboratorium Terpadu UIN Syarif Hidayatullah Jakarta atas kesempatannya untuk melakukan penelitian ini.

\section{DAFTAR PUSTAKA}

1. Antari, A.A Raka Juni dan I. K. Sundra. 2002. Kandungan Pb pada Tanaman Peneduh Jalan Di Kota Denpasar: Jurnal. Universitas dayana. Denpasar. http://ejournal.unud.ac.id/. 4 January 2010.

2. Bandung.http://www.sith.itb.ac.id/profile/datab uendah/publication/7.IATP I2006.pdf. 26 Januari 2010.

3. Rachmawati, D. 2005. Peranan Hutan Kota dalam Menjerap dan Menyrap Pb di Udara Ambien (Studi Kasus). Institut Pertanian Bogor. Bogor.

4. Rumput di Sepanjang Jalan Jendral Sudirman Jakarta. Makalah BATAN Vol. XVI No.4. BATAN- Serpong. ISSN 0303-2876.

5. Sastrawijaya, T. 1996. Pencemaran Lingkungan. Rineka Cipta. Surabaya.

6. Sembiring dan Sulistyawati. 2006. Akumulasi $\mathrm{Pb}$ dengan Pengaruhnya padaKondisi Daun 
Swietenia Marcophyllya king. Institut Teknologi Bandung.

7. Siregar, Edi Batara Mulya. 2005. Pencemaran Udara, Respon Tanaman dan Pengaruhnya Pada Manusia. Fakultas Pertanian. Universitas Sumatera Utara.

8. Soedomo, Moestikahadi. 1999. Pencemaran Udara. Institut Teknologi Bandung. Bandung.

9. Sukarsono. 1998. Dampak Pencemaran Udara Terhadap Tumbuhan di Kebun Raya Bogor. Tesis. Institut Pertanian Bogor. Bogor.

10. Sulasmini, Luh Komang M., M. S. Mahendra, dan Komang Arthawa Lila. 2007. Peranan Tanaman Penghijauan Angsana, Bungur, dan Kupu-Kupu Sebagai Penyerap Emisi Pb dan Debu Kendaraan Bermotor Di Jalan Cokroaminoto, Melati, dan Cut Nyak Dien Di Kota Denpasar. Jurnal. Pertanian Ecotrophic 2 (1) : 1- 11 .
11. Sunarya, W.L.R. Kusmadji, A. Djalil, E. Nurdin, W. Whardana dan I. M. Idil. 1991. Tumbuhan sebagai Bioindikator Pencemaran Udara oleh Timbal. Prosiding Seminar Hasil Penelitian Perguruan Tinggi. Direktorat Pembinaan Penelitian dan Pengabdian pada Masyarakat. Depdikbud Jakarta.

12. Surtipanti. S, Suwira. S, Sofyan. Y, Thamzil. L. 1983. Studi Kandungan Pb dalam Rumput di Sepanjang Jalan Jendral Sudirman Jakarta. Makalah BATAN Vol. XVI No.4. BATANSerpong. ISSN 0303-2876.

13. Widagdo, Setyo. 2005. Tanaman Elemen Lanskap Sebagai Biofilter untuk Mereduksi Polusi $\mathrm{Pb}(\mathrm{Pb})$ di Udara. Skripsi. Institut Pertanian Bogor. Bogor.

14. Widowati, W., A. Sastiono, R. Jusuf R . 2008. Efek Toksik Logam. Andi. Yogyakarta. 